\title{
Sea foam as an object of sea-surface film studies
}

\author{
NIKOLAI V. DRUZHKOV, PAVEL R. MAKAREVICH and SERGEI I. BARDAN
}

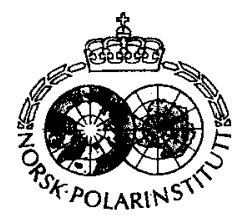

Druzhkov, N. V., Makarevich, P. R. \& Bardan, S. I. 1997: Sea foam as an object of sea-surface film studies. Polar Research 16(2), 117-121.

Sea foam and sea-surface films are pelagic habitats of common origin. This suggests a possible similarity between their microplanktonic assemblages and an a priori possibility to use foam samples in qualitative sea-surface film studies. The composition and abundance of microheterotrophs (nanoflagellates $<5 \mu \mathrm{m}$ and bacteria) in the Dalnezelenetskaya Inlet, Kola Peninsula, Barents Sea, in August 1987, was nearly identical in the foam and sea-surface film samples. In contrast, the enrichment of foam with autotrophs (nano- and microphytoplankton) exceeded by an order of magnitude that of sea-surface films, whereas their taxonomic compositions were virtually identical in both habitats. Elevated growth rates of phytoplankton in sea foam appear to be an ecological mechanism responsible for the enrichment.

N. V. Druzhkov, P. R. Makarevich and S. I. Bardan, Murmansk Marine Biological Institute, Department of Plankton and Microbiology, 184631 Murmansk Region, Dalnie Zelentsy, Russia.

\section{Introduction}

At present, the methods for studying the biology of sea-surface films are subject to ardent criticism. Different sampling devices (Garret 1965; Harvey 1966; Daumas et al. 1976; Van Vleet \& Williams 1980; Carlson 1982; Ignatiades 1987) do not adequately sample sea-surface films due to variable entrapment of the underlying layer of the water column. Sea-surface films may be $>200 \mu \mathrm{m}$ thick and thus introduce considerable and unpredictable distortions of the information on the structure of microhyponeuston communities (Williams et al. 1986). The situation is aggravated by the absence of adequate methods for obtaining realistic in-situ estimates of the thickness of sea-surface films. As a result available estimates of the numbers and biomass of microorganisms inhabiting sea-surface films may differ from real levels by several orders of magnitude. Since all known modifications of the samplers do not solve the above methodological problem, we have changed the very object of investigation to the study of sea foam.

Some detailed investigations exist which deal with the biological and chemical characteristics of sea foam (Khailov 1971; Baire et al. 1974; Velimirov 1980), but the origin of this habitat has not previously been considered to be related to the sea-surface films. The formation of sea-surface films at the air-water interface is due to the processes that lower the level of free energy and which are accompanied by the adsorption of organic matter (Horne 1969). At sites where seasurface films are mechanically compressed, tightly packed slicks emerge, appearing like mirrorsmooth patches and bands on a rough sea surface (Williams 1967). Typical sites of slick formation in open areas are convergence zones (Shienok 1986). Mechanical condensation of sea-surface films through slicks to stable foam is mediated by mixing processes accompanied by intense frothing with entrapped air bubbles. This may occur, for example, by wave breaking, Langmuir circulation, mixing of fresh and salt water, or as a result of forced compression against shores (Williams 1967; Velimirov 1982; Shienok 1986). The formation of foam is therefore structurally related to sea-surface films, and a priori one can expect certain biological similarities in both habitats, especially since the life-span of sea foam seldom exceeds a few hours. The most conspicuous exception to this rule may be the foam ridges that arise from Phaeocystis blooms along the North Sea shores (Lancelot et al. 1987).

We here compare sea-surface films and sea foam by the surface/volume factor, which allows estimates of the influence of linear dimensions on the biological properties of these habitats. Given that sea-surface films and slicks vary from 1 to $10 \mu \mathrm{m}$ in thickness (Williams et al. 1986), the surface/volume factor ranges from 2000 to 20,000 . For sea foam, considering that the thickness of bubble walls averages $5 \mu \mathrm{m}$ (Popov et al. 1979), the corresponding value is about 4000. Therefore, the surface/volume factors of 
both habitats are quite comparable, suggesting that they are also comparable with respect to microplankton assemblages that are "imprisoned" by their formation.

Sea-surface films and sea foam are of common origin. As a rule, sea foam is a short-lived and not a specific habitat of marine ecosystems. Adequate sampling of stable foam does not give rise to any methodical difficulties compared with the sampling of sea-surface films. Foam samples are therefore believed to be useful in studying the composition and some biological properties of sea-surface film microbiota. In order to verify this suggestion, we have undertaken research to compare microplanktonic assemblages that occupy three different habitats: sea-surface films, stable sea foam, and the underlying layer of the coastal pelagic zone.

\section{Material and methods}

Sampling was carried out in the coastal zone of the southern Barents Sea (Dalnezelenetskaya Inlet: $69^{\circ} 07^{\prime} \mathrm{N} ; 36^{\circ} 05^{\prime} \mathrm{E}$ ) on 31 August 1987 , when an intense formation of sea foam (a rather rare ecological event in the study area) was observed after a three-day period of rough weather. During the sampling period, relatively calm weather combined with sufficiently large patches of foam (up to $30-40 \mathrm{~cm}$ in diameter) floating on the sea surface favoured accurate collection of materials.

Samples of foam, accumulated in the embayment by the onflowing tide, were collected by means of a thin plastic sheet without touching the sea surface. They were then allowed to settle to fluid state in 1-liter glass vials for 20-30 $\mathrm{min}$. Settling was conducted in a refrigerator at the ambient temperature of about $7^{\circ} \mathrm{C}$. Sea-surface film samples were collected by a screen sampler as used by Carlson (1982). The top $10 \mathrm{~cm}$ layer was sampled with a 1-liter sampling bottle (culturing flask, $3 \mathrm{~cm}$ width), oriented parallel to the sea surface.

The enumeration of autotrophic nanoplankton was carried out under the epifluorescent microscope MLD-1 in $25-50 \mathrm{ml}$ live samples which were concentrated on $0.65 \mu \mathrm{m}$ polycarbonate membrane filters (Dubna, Moscow Region) at 280× magnification (Druzhkov \& Makarevich 1987).
One to two-liter microphytoplankton samples, concentrated to $30-40 \mathrm{ml}$, were screened over $1 \mu \mathrm{m}$ polycarbonate membrane filters with a reverse flow device (Sukhanova 1983) and then preserved with buffered formalin (final concentration $1 \%$ ). Microalgal cells were counted and identified in $0.5 \mathrm{ml}$ counting chambers ( 5 replicas) after repeated reduction of sample volumes to 2-3 ml by sedimentation (Fedorov 1979; Tsyban 1982).

Live samples of heterotrophic nanoplankton were enumerated in the $0.5 \mathrm{ml}$ counting chambers ( 5 replicas) in phase contrast (BIOLAR) at $350 \times$ magnification. Only moving cells of $1-5 \mu \mathrm{m}$ size were counted because counting of the larger and motile flagellates was beyond the capacity of the method. Because accurate visual separation of large motile bacteria from the smallest motile protists was extremely difficult within the limits of the method used (see Cynar et al. 1985), we considered it reasonable to combine all the counted cells into one group of nanoheterotrophs.

One-milliliter bacterioplankton samples were concentrated on $0.11 \mathrm{~m}$ black polycarbonate membrane filters and preserved with $96 \%$ ethanol. The filters were stained with fluorescamin according to the method of Poglazova \& Mitskevich (1984), and bacterial cells were counted under the epifluorescence microscope MLD-1 at $1250 \times$ magnification.

Enrichment indices (E) were calculated as ratios between the densities of microplankton in sea-surface films and sea foam, and those in the top pelagic zone. All data presented below are means of three replicas. The corrected concentrations of plankton organisms for sea-surface film (Tables 1 and 2) were calculated from the following assumptions: (1) the thickness of a sampled layer is about $200 \mu \mathrm{m}$ (Carlson 1982); (2) the thickness of the proper sea-surface film is $5 \mu \mathrm{m}$; (3) the water that is in direct contact with the highly structured sea-surface film layer is biologically similar with the water from $10 \mathrm{~cm}$ depth due to continuous microconvection at the air-water interface (Fedorov \& Ginzburg 1992).

\section{Results and discussion}

The numbers of microplankton presented in Table 1 indicated intense concentrating in sea-surface films and sea foam, a phenomenon well known for 
Table 1. Abundance $\left(10^{3}\right.$ cells $\left.\mathrm{ml}^{-1}\right)$ of various microplanktonic groups in sea foam, sea-surface film and top pelagic zone $(10 \mathrm{~cm}$ layer).

\begin{tabular}{lcccc}
\hline Habitat & $\begin{array}{c}\text { Nanophyto- } \\
\text { plankton }\end{array}$ & $\begin{array}{c}\text { Microphyto- } \\
\text { plankton }\end{array}$ & $\begin{array}{c}\text { Heterotrophic } \\
\text { nanoplankton }\end{array}$ & Bacterioplankton \\
\hline Sea foam & 283.3 & 7.1 & 6.7 & 78.9 \\
Sea-surface film: & & & 0.3 & 2.1 \\
$\quad$ measured concentrations & 1.2 & 0.01 & 7.9 & 62.8 \\
$\quad$ corrected concentrations & 40.4 & 0.4 & 0.1 & 0.5 \\
\hline
\end{tabular}

Table 2. Calculated enrichment indices (E) for sea foam and sea-surface film.

\begin{tabular}{|c|c|c|c|c|c|c|c|}
\hline \multirow[b]{2}{*}{ Habitat } & \multicolumn{4}{|c|}{ Nanophytoplankton } & \multirow{2}{*}{$\begin{array}{l}\text { Microphyto- } \\
\text { plankton }\end{array}$} & \multirow{2}{*}{$\begin{array}{l}\text { Nanophyto- } \\
\text { plankton }\end{array}$} & \multirow{2}{*}{$\begin{array}{l}\text { Bacterio } \\
\text { plankton }\end{array}$} \\
\hline & $1-8 \mu \mathrm{m}$ & $9-16 \mu \mathrm{m}$ & $17-24 \mu \mathrm{m}$ & Total & & & \\
\hline Sea foam & 1240 & 1694 & 3750 & 1334 & 2554 & 107 & 142 \\
\hline \multicolumn{8}{|l|}{ Sea-surface film: } \\
\hline measured concentrations & 5 & 7 & 5 & 6 & 4 & 4 & 4 \\
\hline corrected concentrations & 179 & 254 & 200 & 197 & 137 & 128 & 113 \\
\hline
\end{tabular}

Table 3. Percentage of three dominant taxa of diatoms (\% of the total microphytoplankton number), three size groups of the nanophytoplankton (\% of the total nanophytoplankton number), and four morphological groups of the bacterioplankton (\% of the total bacteria number) in sea foam, sea-surface film and the top pelagic zone (standard error of per cent given in parentheses).

\begin{tabular}{|c|c|c|c|}
\hline Taxa & Sea foam & Sea-surface film & Top pelagic zone \\
\hline \multicolumn{4}{|l|}{ Microphytoplankton: } \\
\hline Licmophora sp. & $56.7(1.51)$ & $77.7(2.78)$ & $53.6(5.09)$ \\
\hline Leptocylindrus danicus & $1.1(0.32)$ & $3.2(1.17)$ & $4.3(2.07)$ \\
\hline Navicula spp. & $22.3(1.27)$ & $15.4(2.41)$ & $23.2(4.31)$ \\
\hline \multicolumn{4}{|l|}{ Nanophytoplankton: } \\
\hline $1-8 \mu \mathrm{m}$ & $89.7(1.17)$ & $90.6(1.86)$ & $93.2(3.80)$ \\
\hline $9-16 \mu \mathrm{m}$ & $9.0(1.10)$ & $8.9(1.81)$ & $6.8(3.80)$ \\
\hline $17-24 \mu \mathrm{m}$ & $1.3(0.43)$ & $0.4(0.40)$ & 0.0 \\
\hline \multicolumn{4}{|l|}{ Bacterioplankton: } \\
\hline Bacilli & $26.9(5.71)$ & $28.0(5.94)$ & $18.2(5.00)$ \\
\hline Cocci & $50.0(6.65)$ & $52.1(6.57)$ & $56.8(6.61)$ \\
\hline Coccobacilli & $22.4(5.50)$ & $18.7(5.68)$ & $23.9(5.08)$ \\
\hline Ellipsoid forms & $1.7(1.71)$ & $1.3(1.50)$ & $1.1(1.38)$ \\
\hline
\end{tabular}

highly structured contact microlayers (Bezdek \& Carlucci 1972; Hardy 1982; Williams et al. 1986; Cullen et al. 1989). Most surprising was the fact that the abundance of autotrophs exceeded that of heterotrophs by an order of magnitude. Apparently, the enrichment of sea foam with microplankton exceeded that of sea-surface films by several orders of magnitude (Table 2). However, there is an evident underestimation of the biomass in sea-surface films due to a sampling procedure that cannot exclude the entrapment of water from the layer, underlying sea-surface films.
Using the correction method described above, the corrected concentrations of plankton organisms in sea-surface film (Table 1) and enrichment indices calculated for these concentrations (Table 2) differ considerably from the corrected values. For heterotrophs, the corrected densities and enrichment indices for sea-surface film were similar to the values recorded in foam. In contrast, the numbers and indices calculated for both seasurface film microalgal groups were lower than their abundance in foam by an order of magnitude. For diatoms, the above lack of similarity 
cannot be easily explained by differences in microalgal taxonomic composition. Indeed, the relative abundances of dominant taxa were not significantly different in any of the microphytoplankton assemblages (Table 3). Small benthic diatoms accounted for 80.1 to $96.3 \%$ of microalgal biomass in all three habitats.

The similarity of the microheterotrophic communities from sea-surface film and sea foam would suggest a common origin of two structures, whereas the much stronger enrichment of the sea foam with nano- and microphytoplankton contradicts such a suggestion. The elevated concentrations of autotrophs in the foam samples may be explained by the active migration from seasurface films, differential adherence, or, more probably, by a considerable increase of growth rates, resulting in a rapid rise in micro algal biomass (Hardy 1982; Catalan 1986). In general, there is an evident similarity in microbiotas from sea-surface film and sea foam. The similar percentage compositions of microphytoplankton, nanophytoplankton and bacterioplankton (Table 3 ) in these two habitats suggest a tightly coupled genesis of the assemblages. Moreover, our results also demonstrate a similarity of the microbiotas from these two habitats with that of the top layer of the pelagic zone. Significant differences were recorded only for the largest fractions of microalgae, i.e. diatoms and flagellates of $17-24 \mu \mathrm{m}$ size (Table 3 ). These differences are quite understandable since the walls of foam cells are too thin to provide a habitat appropriate to the organisms larger than 5-10 $\mu \mathrm{m}$.

There is no complete identity between the assemblages inhabiting the sea foam and seasurface film. Sea foam as living space for unicellular organisms is characterised by extremely specific chemical and physical properties (Velimirov 1980, 1982; Bärlocher et al. 1988; Craig et al. 1989). In turn, the characteristics of sea-surface films and sea foam are strongly dependent on the metabolic activity and composition of microplankton (especially on those of microalgae) in the subsurface bulk water, demonstrating clear seasonal variability (Craig et al. 1989; Hardy \& Apts 1989; Saliot et al. 1991; Gladyshev et al. 1993). It seems therefore true that the problem of the biological and chemical similarity between the two habitats is multidimensional and has no simple solution. The above results have demonstrated that there is some support for the formulation of a new quantitative approach to sea-surface film and sea foam research since the composition of microheterotrophs and their enrichment indices were rather similar in the two habitats. A few earlier reports indicated the relative independence of the abundance of bacterioneuston and their enrichments from physical and chemical variables (Maki \& Remsen 1988). Therefore, further joint studies of microplankton in the two habitats should be of great interest.

Acknowledgements. - We are deeply grateful to $O$. N. Baitaz and the late V. A. Baitaz for preparing the data on bacterioplankton.

\section{References}

Baire, R. E., Groupil, D. W., Perlmutter, S. \& King, K. 1974: Dominant chemical composition of sea-surface films, natural slicks, and foams. J. Rech. Atmos. 8, 571-600.

Bärlocher, F., Gordon, J. \& Ireland, R. J. 1988: Organic composition of seafoam and its digestion by Corophium volutator (Pallas). J. Exp. Mar. Biol. Ecol. 115, 179-186.

Bezdek, H. F. \& Carlucci, A. F. 1972: Surface concentration of marine bacteria. Limnol. Oceanogr. 17, 566-569.

Carlson, D. J. 1982: A field evaluation of plate and screen microlayer sampling techniques. Mar. Chem. 11, 189-208.

Catalan, J. 1986: Approximacion a la composicion y organization del neuston. Oekol. Aquat. 8, 25-38.

Craig, D, Ireland, R. F. \& Bärlocher, F. 1989: Seasonal variation in the organic composition of seafoam. J. Exp. Mar. Biol. Ecol. 130, 71-80.

Cullen, J. J., MacIntyre, H. L. \& Carlson, D. J. 1989: Distributions and photosynthesis of phototrophs in seasurface films. Mar. Ecol. Prog. Ser. 55, 271-278.

Cynar, F. J., Estep, K. W. \& Sieburth, J. McN. 1985: The detection and characterization of bacteria-sized protist in +protist-free + filtrates and their potential impact on experimental marine ecology. Microb. Ecol. 11, 281-288.

Daumas, R. A., Laborde, P. L., Marty, J. C. \& Saliot, A. 1976: Influence of sampling method on the chemical composition of water surface films. Limnol. Oceanogr. 21, 319-326.

Druzhkov, N. V. \& Makarevich, P. R. 1987: Nanophytoplankton. Pp. $10-11$ in Makarevich, P. R. \& Druzlikov, N. V. (eds.): Metodicheskie rekomendatsii po analizu kolichestvennykh i funktsionalnykh kharakteristik morskikh biotsenozov severnykh morei. Tsast 1. Fitoplankton. Zooplankton. Organ itseskoe veshestvo (Methodical recommendations on the analysis of quantitative and functional characteristics of the arctic marine ecosystems. Part I. Phytoplankton. Zooplankton. Particulate organic matter). Kolsky Nauchny Tsentr Rossiyskoi Akademii Nauk (Kola Science Centre of Russian Academy of Sciences), Apatity (in Russian).

Fedorov, K. N. \& Ginzburg, A. 1. 1992: The Near-Surface Layer of the Ocean. VSP, Utrecht. $259 \mathrm{pp}$.

Fedorov, V. D. 1979: O metodakh izucheniya fitoplanktona $i$ ego aktivnosti (On the methods of study of phytoplankton and their activity). Izdatelstvo Moskovskogo Universiteta (Moscow Univ. Press), Moskva. 168 pp. (in Russian). 
Garret, W. D. 1965: Collection of slick-forming materials from the sea surface. Limnol. Oceanogr. 10,602-605.

Gladyshev, M. J., Kalachova, G. S. \& Sushchik, N. 1993: Free fatty acids of surface film of water in the Sydinsky Bay of the Krasnoyarsk Reservoir. Int. Rev. Gesamt. Hydrobiol. 78, 575-587

Hardy, J. T. 1982: The sea surface microlayer: biology, chemistry and anthropogenic enrichment. Progr. Oceanogr. 11, 307-328.

Hardy, J. T. \& Apts, C. W. 1989: Photosynthetic carbon reduction: high rates in the sea-surface microlayer, $\mathrm{Mar}$. Biol. 101, 411-417.

Harvey, G. W. 1966: Microlayer collection from the sea surface: a new method and initial results. Limnol. Oceanogr. $11,608-613$.

Horne, R. A. 1969: Marine Chemistry. The Structure of Water and the Chemistry of the Hydrosphere. Wiley-Interscience, Div. of John Wiley \& Sons, New York. 398 pp.

Ignatiades, L. A. 1987: A simple apparatus for sampling sea surface microlayers. Mar. Ecol. Prog. Ser. 39, 207-208.

Khailov, K. M. 1971: Ekologitsesky metabolizm $v$ more (Ecological metabolism in the sea). Naukova Dumka, Kiev. 252 pp. (in Russian)

Lancelot, C., Billen, G., Sournia, A., Weisse, T., Colijn, F., Veldhuis, M. J. W., Davies, A. \& Wassman, P. 1987: Phaeocystis blooms and nutrient enrichment in the continental coastal zones of the North Sea. Ambio 16, 38-46.

Maki, J. S. \& Remsen, C. C. 1988: Examination of a freshwater surface microlayer for diel changes in the bacterioneuston. Hydrobiologia 182, 25-34.

Poglazova, M. N. \& Mitskevich, I. N. 1984: Primenenie fluoreskamina dlya opredeleniya kolichestva mikroorganizmov v morskoi vode epifluorestsentnym metodom. Mikrobiologiya (Application of fluorescamin for assessment of bacteria abundance in the sea water with the use of the epifluorescence microscopy). Mikrobiologiya 53, 850-858 (in Russian).

Popov, N. I., Fedorov, K. N. \& Orlov, V. M. 1979: Morskaya yoda (Sea Water) Nauka, Moscow. 327 pp. (in Russian)

Saliot, A., Marty, J. C., Scribe, P., Siore, M. A., Viets, T. C., de Leeuw, J. W., Schenck, P. A. \& Boon, J. J. 1991: Charac- terization of particulate organic matter in Mediterranean seasurface films and underlying water by flash pyrolysis and gas chromatographic analyses. Org. Geochem. 17, 329-340.

Shienok, V. A. 1986: Î kharaktere vetrovogo vozdeistviya na ekosistemu melkogo vodoyoma (Impact of the wind activity on the ecosystem of shallow basins). Pp. 217-218 in: 5 Syezd Vsesoyuznogo gidrobiologicheskogo obshestva, Toliyatti, 15-19 Sentyabrya 1986 goda. Tsast I (Proceedings of the Fifth All-Union Conference of the All-Union Hydrobiological Society, Toliyatti, 15-19 September 1986. Part I). Kuibyshevskoe Knizhnoe Izdatelstvo, Kuibyshev (in Russian). Sukhanova, I. N. 1983: Kontsentrirovanie fitoplanktona $\mathrm{v}$ probe (Concentrating the phytoplankton samples). Pp. 97-108 in Vinogradov, E. M. (ed.): Sovremennye metody kolichestvennoi otsenki raspredeleniya morskogo planktona (The modern methods of the quantitative assessment of marine plankton distribution). Nauka, Moscow (in Russian).

Tsyban, A. V. (ed.). 1982: Rukovodstvo po metodam biologicheskogo analiza morskoi vody $i$ donnykh otlozheniy (Manual of biological analyses of seawater and bottom sediments). Gidrometeoizdat, Leningrad. 191 pp. (in Russian).

Van Vleet, E. S. \& Williams, P. M. 1980: Sampling sea surface films: a laboratory evaluation of techniques and collecting materials. Limnol. Oceanogr. 25, 764-770.

Velimirov, B. 1980: Formation and potential trophic significance of marine foam near kelp beds in the Benguela upwelling system. Mar. Biol. 58, 311-318.

Velimirov, B. 1982: Sugar and lipid components in sea foam near kelp beds. Mar. Ecol. 3, 97-107.

Williams, P. M. 1967: Sea surface chemistry: organic carbon, nitrogen and phosphorus in surface films and subsurface water. Deep-Sea Res. 14, 781-800.

Williams, P. M., Carlucci, A. F., Henrichs, S. M., Van Vleet, E. S., Horrigan, S. G., Reid, F. M. H. \& Robertson, K. J. 1986: Chemical and microbiological studies of sea-surface films in the Southern Gulf of California and off the west coast of Baja California. Mar. Chem, 19, 17-98. 